Ethiopian Journal of Environmental Studies \& Management 10(4): 482 - 491, 2017.

ISSN:1998-0507

doi: https://dx.doi.org/10.4314/ejesm.v10i4.6

Submitted: December 12, 2016

Accepted: May 26, 2017

\title{
PRODUCTION OF BIOGAS FROM COW DUNG, WEEDS AND DOMESTIC WASTES
}

\author{
ONWUKEME, V.I., ${ }^{1}$ *ETIENAJIRHEVWE, O.F. ${ }^{2}$ AND MOKOBIA, E.K. ${ }^{2}$ \\ ${ }^{1}$ Department of Pure and Industrial Chemistry, Nnamdi Azikiwe University, Awka, \\ Anambra State, Nigeria \\ ${ }^{2}$ Chemistry Unit, Department of Science Laboratory Technology, Delta State Polytechnic, \\ Otefe, Oghara, Nigeria
}

\begin{abstract}
Biogas production was carried out using cow dung, weeds, orange peelings and corn cob. Four different set of experiments were set up to demonstrate the production of biogas by the anaerobic fermentation of weeds and domestic waste; to determine the ratios of cow dung to weeds, orange peelings, and corn cob which would be required for optimum gas production; to determine the burning characteristic of the gas produced and to determine the time taken for a digester to start biogas production when activated with a slurry from already functioning digester. Results obtained showed that production of biogas by anaerobic fermentation oOf cow dung and wastes began on day 7 with $48 \mathrm{~cm}^{3}$ of gas with a total volume of $1758 \mathrm{~cm}^{3}$ at the end of 22 days. The results of various percentage combination of cow dung and weeds, orange peelings and corn cob showed gas production on day 6 in $75 \%$ cow dung and 25\% weeds with $6 \mathrm{~cm}^{3}$ of gas followed by $50 \%$ cow dung and $50 \%$ weeds on day 7 while $25 \%$ cow dung and $75 \%$ orange peelings started on day 8 while 25\% cow dung and 75\% corn cob started on day 9. 50\% cow dung and 50\% weeds produced the highest volume of gas $\left(779 \mathrm{~cm}^{3}\right)$ while $25 \%$ cow dung and $75 \%$ corn cob produced the lowest $\left(474 \mathrm{~cm}^{3}\right)$. The gas produced by a restarted digester began on day 3 with $41 \mathrm{~cm}^{3}$ of gas and a total volume of $3579 \mathrm{~cm}^{3}$ at the end of 22 days.
\end{abstract}

Key Words: Biogas, Cowdung, Digester and Fermentation

\section{Introduction}

The process of biogas production by the anaerobic fermentation of organic matter is a technology which is gaining popularity daily and in more widely adopted for use (Karla 1990). This development is due to its ability to provide relief to man from two of the problems encountered in the course of living from day to day; they are the problem of how to acquire energy in sufficient amount for purpose of cooking, heating, lighting and running of machinery on one hand and the problem of proper disposal of waste in manner that is would not cause harm to man or damage its environment (Nianguo, 1987).

There is an unquenchable need for energy for cooking, lighting, heating and running of machineries; the need of energy for purpose of cooking, lighting, and heating has already been a problem

*Corresponding Author: Etienajirhevwe, O.F.

Email: omonigho4jesus@yahoo.com 
to man since primitive man first discovered fire (Diavwairu, 2003). Though there is a growing concern for a steady, cheap and adequate supply of energy in the world today, there is a wide gap, which has kept increasing in the amount of energy supplied and consumed in the developed nations and the developing nations; the developing nations are plagued by problems of lack of a fully, and poor utilization of resources which was a significant section of the population with no option other than to result to personal provision of energy required for individual consumption (Gutert, 2002).

Fowler and Joshi (1994) studied the anaerobic fermentation of materials such as newspapers, filter, paper, banana skins, etc at the Indian Institute of Science, Bangalore, India. They found materials rich in hemicellulouses to be producers of gas rich in methane. Dynatech Research and Development carried out experiment which demonstrates the continuous conversion of $\mathrm{CO}, \mathrm{CO}_{2}$ and $\mathrm{H}_{2}$ to $\mathrm{CH}_{4}$ by anaerobic fermentation. They also demonstrated the production of acetic acid from $\mathrm{CO}_{2}$ and $\mathrm{H}_{2}$ by anaerobic fermentation.

The socio economic implication of this is research is that this process can continues as long as cow dung is continued to be generated as a waste which is another way of waste management. This process eliminates waste of fund for the purchase of methane gas and other source of heat for domestic use. Already used material for the production of biogas could also be used as manure (Eruedede, 2012)

This work is therefore aimed to demonstrate the production of biogas by the anaerobic fermentation of domestic waste, to determine the ratio of weeds, and orange peeling and corn cob which would produce optimum amount of gas to test the burning of the gas and its burning characteristics and to determine the time taken for biogas production to begin when restarting a digester.

\section{Materials and Method}

\section{Collections and Preparation of Samples}

Cow dung, orange peeling, and corn cob were the domestic waste used. The weeds used were carpet grass (Axonopus compresus) and goose grass (Eleuisine indica). The cow dung was obtained from a rearing farm in Oghara, Delta State, Nigeria The waste was obtained dry. It was packed into sack bag before being transported to the site of the experiment. The orange peelings and corn cob were obtained from waste site in Oghara, Delta state Nigeria, they were obtained fresh and put in polythene bags before they were transported to the site of the experiment

The weeds were collected fresh. They were harvested in Oghara community, Delta State, Nigeria. The materials were not dried before use. There was no chemical treatment, the cow dung were used as collected, the orange peelings and were beaten into pulp before used which the weeds were chopped into smaller sizes. The digesters used were made of transparent plastic containers of $500 \mathrm{~cm}^{3}$ and $1500 \mathrm{~cm}^{3}$ capacity. They were wrapped in black polythene bags to keep out of light. This was done since it was not known if the bacterial are sensitive to light. The gas to be produced was designed to leave digester by means of delivery tube and was connected into a measuring cylinder which was used as the gas measuring device. The delivery 
tube had a tap for regulating the gas flow. The gas was collected by upward directly over water.

\section{Experimental set up}

Set-up 1:

This was done to demonstrate the production of biogas by the anaerobic fermentation of weeds and domestic waste.

\section{Procedure:}

$30 \mathrm{~g}$ of cow dung, $35 \mathrm{~g}$ of weeds and $35 \mathrm{~g}$ of orange peeling and corn cob were weighed into the plastic container of capacity $15000 \mathrm{~cm}^{3} .1000 \mathrm{~cm}^{3}$ of tap water was added to the content and was stirred and allowed to stand for 24 hours. The digester was then sealed and the entire set-up arranged.

\section{Set-up 2:}

This was done to determine the ratio of cow dung to weed, and cow dung to orange peelings and corn cob, which would be required for optimum gas production.

\section{Procedure:}

Set-up 2a:

$25 \%$ cow dung and $75 \%$ weed. $10 \mathrm{~g}$ of cow dung and $30 \mathrm{~g}$ of weed were weighed into the plastic container of $500 \mathrm{~cm}^{3}$ capacity, $400 \mathrm{~cm}^{3}$ of water was added and the content stirred and arranged.

Set-up 2b: $50 \%$ cow dung and 50\% weed. $20 \mathrm{~g}$ of cow dung and $20 \mathrm{~g}$ of weed were weighed into the plastic container of capacity $500 \mathrm{~cm}^{3} .400 \mathrm{~cm}^{3}$ of water was added to the content, stirred and arranged

\section{Set-up 2c:}

$75 \%$ cow dung and $25 \%$ weed. $20 \mathrm{~g}$ of cow dung and $10 \mathrm{~g}$ of weeds were weighed into the plastic container of capacity $500 \mathrm{~cm}^{3}, 400 \mathrm{~cm}^{3}$ of water was added and the content was stirred and arranged
Set-up 2d:

$25 \%$ cow dung and $75 \%$ corn cob. $10 \mathrm{~g}$ of cow dung and $30 \mathrm{~g}$ of corn cob were weighed into the plastic container; $400 \mathrm{~cm}^{3}$ of water was added, stirred and arranged.

Set up $2 e$

$25 \%$ cow dung and $75 \%$ corn cob. $10 \mathrm{~g}$ of cow dung and $30 \mathrm{~g}$ of corn cob was weighed into the plastic container followed by $400 \mathrm{~cm}^{3}$ of water, stirred and was arranged.

Set-up 3:

This was done to determine the burning characteristics of the gas produced.

\section{Procedure}

$100 \mathrm{~g}$ of cow dung and $200 \mathrm{~g}$ of weeds were weighed into reasonable container; $1500 \mathrm{~cm}$ of water was added. The content was agitated covered and sealed. The set up was arranged with a Bunsen burner in place of the measuring cylinder.

\section{Set up 4:}

This was done to determine the time taken for digester to start production when it is activated with slurry form an already functioning digester.

\section{Procedure}

$30 \mathrm{~g}$ of cow dung and $70 \mathrm{~g}$ of weed were weighed into the plastic container of capacity $1250 \mathrm{~cm}^{3}, 400 \mathrm{~cm}^{3}$ of used scurry was added followed by $500 \mathrm{~cm}^{3}$ of tap water and a delivery tube was connected into a measuring cylinder which served as the gas measuring device. No heat was applied as ambient temperature which was $29-32^{\circ} \mathrm{C}$ was used.

\section{Statistical Analysis}

Data obtained from the various experimental set ups were checked by using Minitab statistical package. Descriptive statistical analysis was carried out to check the mean and variance of the collected data. Difference 
Production of Biogas from Cow Dung, Weeds and Domestic Wastes.................NWUKEME et al.

between the contributions various production were checked by $\mathrm{F}$ - test experimental materials to biogas (ANOVA)

\section{Results}

Result obtained from biogas production using different percentage waste and weeds. $\left(\mathrm{cm}^{3}\right)$.

Table 1: Volume of gas produced per day by domestic waste a need from set-up 1

\begin{tabular}{lll}
\hline Days & Gas produced $\left(\mathrm{cm}^{3}\right)$ & Cumulative volume $\left(\mathrm{cm}^{3}\right)$ \\
\hline 1 & - & - \\
2 & - & - \\
3 & - & - \\
4 & - & - \\
5 & - & - \\
6 & - & - \\
7 & 48 & 48 \\
8 & 54 & 102 \\
9 & 56 & 158 \\
10 & 70 & 228 \\
11 & 76 & 304 \\
12 & 89 & 393 \\
13 & 107 & 500 \\
14 & 136 & 636 \\
15 & 147 & 783 \\
16 & 147 & 930 \\
17 & 144 & 1074 \\
18 & 145 & 1219 \\
19 & 143 & 1362 \\
20 & 136 & 1498 \\
21 & 132 & 1630 \\
22 & 128 & 1758 \\
\hline
\end{tabular}

Volume of gas produced by anaerobic fermentation of domestic waste and weeds obtained from set up 1 
Table 2: Volume of gas produced daily by various ratios of cow dung to organic was weed from set up $2 \mathrm{~A}-2 \mathrm{E}$.

\begin{tabular}{|c|c|c|c|c|c|}
\hline Days & $\begin{array}{l}25 \% \mathrm{CD}: 75 \% \mathrm{~W} \\
\left(\mathrm{~cm}^{3}\right)\end{array}$ & $\begin{array}{l}50 \% \mathrm{CD}: 50 \% \mathrm{~W} \\
\left(\mathrm{~cm}^{3}\right)\end{array}$ & $\begin{array}{l}\text { 75\%CD:25\%W } \\
\left(\mathrm{cm}^{3}\right)\end{array}$ & 25\%CD75\%:OP $\left(\mathrm{cm}^{3}\right)$ & $25 \% \mathrm{CD}: 75 \% \mathrm{CC}\left(\mathrm{cm}^{3}\right)$ \\
\hline 1 & - & - & - & - & - \\
\hline 2 & - & - & - & - & - \\
\hline 3 & - & - & - & - & - \\
\hline 4 & - & - & - & - & - \\
\hline 5 & - & - & - & - & - \\
\hline 6 & - & - & 6 & - & - \\
\hline 7 & - & 4 & 7 & - & - \\
\hline 8 & 8 & 23 & 15 & 7 & - \\
\hline 9 & 16 & 32 & 26 & 11 & 9 \\
\hline 10 & 17 & 37 & 34 & 18 & 11 \\
\hline 11 & 26 & 40 & 41 & 22 & 16 \\
\hline 12 & 29 & 43 & 46 & 30 & 18 \\
\hline 13 & 33 & 50 & 48 & 36 & 25 \\
\hline 14 & 37 & 55 & 51 & 42 & 38 \\
\hline 15 & 41 & 56 & 56 & 46 & 38 \\
\hline 16 & 45 & 60 & 58 & 48 & 43 \\
\hline 17 & 48 & 62 & 61 & 51 & 45 \\
\hline 18 & 50 & 64 & 63 & 47 & 46 \\
\hline 19 & 49 & 66 & 65 & 45 & 44 \\
\hline 20 & 46 & 65 & 61 & 46 & 48 \\
\hline 21 & 44 & 63 & 57 & 43 & 48 \\
\hline 22 & 38 & 59 & 51 & 41 & 45 \\
\hline Total & 527 & 779 & 746 & 533 & 474 \\
\hline
\end{tabular}

Key: CD - cow dung, W - weed, OP - orange peeling, CC - corn cob.

\section{Result of time taken for biogas produced to burn}

Table 3 characteristics of biogas produced from set-up 3.

\begin{tabular}{ll}
\hline Day of test after gas production biogas & Test for lighting with the aid of match \\
\hline $1-5$ & No burning \\
$6-8$ & Slight burning \\
$9-22$ & Proper burning \\
\hline
\end{tabular}


Production of Biogas from Cow Dung, Weeds and Domestic Wastes.................NWUKEME et al.

\begin{tabular}{lll}
\multicolumn{2}{l}{ Results of Gas Produced For a Restarted Digester } & \\
\hline Days & Daily Gas Production $\left(\mathrm{cm}^{3}\right)$ & Cumulative volume $\left(\mathrm{cm}^{3}\right)$ \\
\hline 1 & - & - \\
2 & - & - \\
3 & 41 & 41 \\
4 & 70 & 111 \\
5 & 81 & 192 \\
6 & 93 & 285 \\
7 & 112 & 397 \\
8 & 130 & 527 \\
9 & 141 & 668 \\
10 & 145 & 813 \\
11 & 156 & 969 \\
12 & 156 & 1125 \\
13 & 158 & 1283 \\
14 & 151 & 1434 \\
15 & 159 & 1593 \\
16 & 149 & 1743 \\
17 & 145 & 1887 \\
18 & 144 & 2031 \\
19 & 141 & 2172 \\
20 & 138 & 2310 \\
21 & 136 & 2440 \\
22 & 133 & 2579 \\
\hline
\end{tabular}

\section{Discussion}

Table 1 gives the result of production of biogas by anaerobic fermentation of cow dung and other domestic wastes. Here, production of biogas began at day 7 of the experiment with $48 \mathrm{~cm}^{3}$ of gas with a steady increase as the experiment progressed. This set-up lasted for a period of 22 days and the highest volume of gas was produced on day 15 and 16 with equal volume of $147 \mathrm{~cm}^{3}$ each. The lowest gas produced was on day 7 which was the day production of gas begun.
Before biogas production began, the micro-organism needed for the biogas production was inactive. This means that the anaerobic bacteria present were using oxygen present in the digester. After this was used up, the acid forming bacteria became active and biogas production began. The volume of gas production each day showed a steady increase until a peak was reached on day 15 and 16 before a decrease was notice till the $22^{\text {nd }}$ day. Figure 1 below showed a plot of the rate of production of biogas by cow dung and other wastes. 


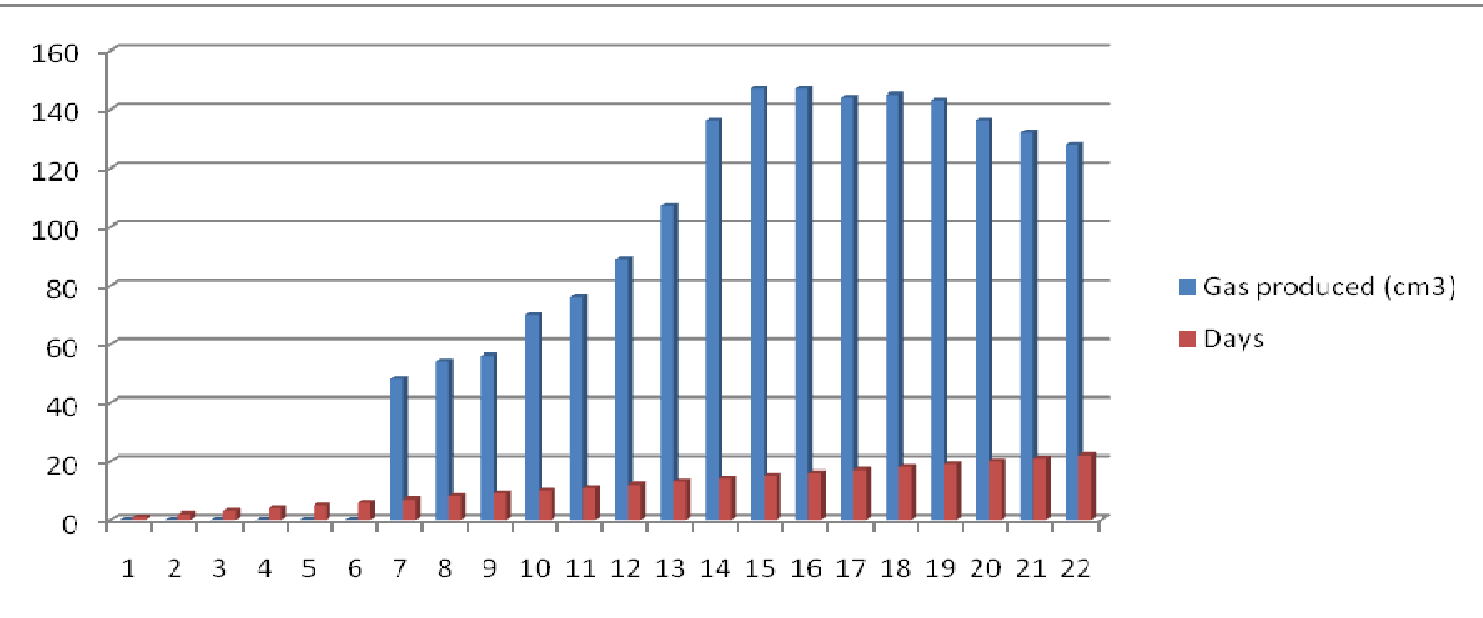

Figure 1: Rate of production of biogas by cow dung and other wastes

Table 2 above presents the results of biogas production of different percentage combination of cow dung to weed, orange peeling and corn cob. Production of biogas began on the sixth day in $75 \%$ cow dung and $25 \%$ weed with $6 \mathrm{~cm}^{3}$ of gas produced which could be due to the bacteria loading of this sample combination knowing that the manure is very rich in microbes compared to plant which are almost sterile. Here, the high microbial loading showed that more microbes would be used up in sealing the digester faster. There would also be higher amount of anaerobic bacteria which began fermentation when the environment became oxygen free. This is the reason while gas production started first. The last sample combination to produce gas was $25 \%$ cow dung and $75 \%$ corn cob which must have occurred as a result of high cellulous content of the corn cob which also have low bacteria loading; this took more time to use up the oxygen in sealing the digester. This means that small amount of anaerobic bacteria present in the combination took more time to establish themselves before gas production began. Sample combination of $25 \%$ cow dung and $75 \%$ weed, and $25 \%$ cow dung and $75 \%$ orange peeling began gas production on the $8^{\text {th }}$ day .This showed some similarities in chemical composition of both the weed and orange peeling. The combination of $50 \%$ cow dung and $50 \%$ weed produced the highest volume of gas $\left(779 \mathrm{~cm}^{3}\right)$ while the lowest was $25 \%$ cow dung and $75 \%$ corn cob $\left(474 \mathrm{~cm}^{3}\right)$. The carbon to nitrogen ratio is regarded as the ratio of elemental carbon present in the material to the elemental nitrogen present in the material. Since different material has different composition, the different mixture therefore altered the overall carbon to nitrogen ration of the total feed stock. This implied that the sample containing $25 \%$ cow dung and $75 \%$ corn cob have the least designable value of carbon to nitrogen ratio.

Figure 2 below thus give a plot of the rate of gas production per day of the different combination of sample materials. 


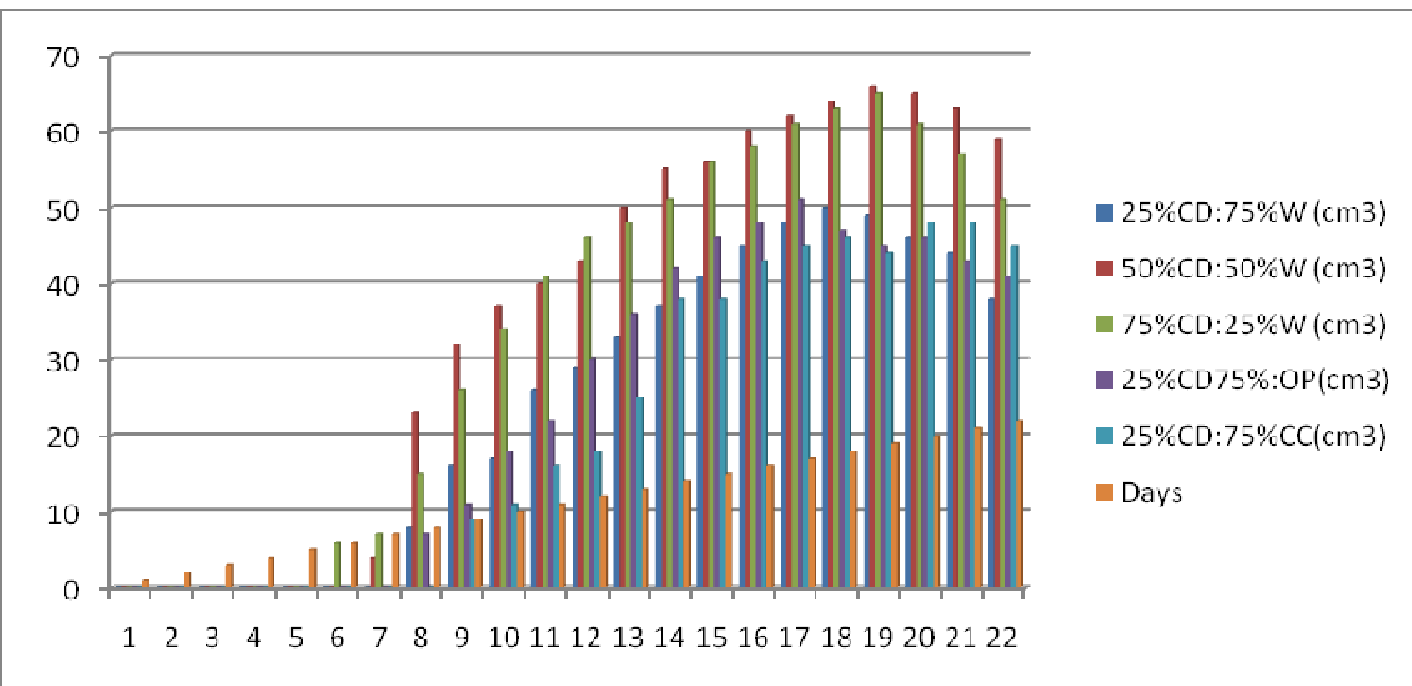

Figure 2: Rate of gas production per day of the different combination of sample materials

The burning character of the biogas is as presented in table 3. Slight burning was observed after 5 days while proper burning began from the 8 day of the set up. During the period of slight burning the content was mostly $\mathrm{CO}_{2}$. Since the methane forming bacteria was not active yet, there was more of the acid taking place in the digester. As the fermentation progressed, the methane forming bacteria started establishing themselves and more of the methane forming phase began to occur. This led to increase in the percentage by volume of the gas being produced. As this occurred the tendency of the gas to burning then increased. As the methane forming phase occurred at maximum capacity with the methanogens acting on the substrate produced by the acid forming bacteria for maximum biogas production, this then made the biogas to burn easily. The flame was thus blue and smokeless which is a characteristic of a methane gas.

The results of the gas produced for a restarted digester is presented in table 4 above showed that the production began at day 3, as against day 6 and 7 of the previous set up. Gas production was noticed to peak earlier compared to the former. This showed that when a digester is set up using slurry from a previous digestion, gas production would begin earlier than expected. This is because the microbes required for the process to occur were already active but only deactivated by the introduction of oxygen. Now the reason why production began on day three is that the oxygen present within the digester was being used by the anaerobic bacteria. As soon as the oxygen was used up, biogas production kicked off fully. Since the set up was reached in bacteria loading, it also took lesser time for the oxygen to be used up. Thus already established bacteria are simply given substrate to act on. They work with shorter time because of their population and reduce the operating time of digester. The increase in volume of gas as shown in table 4 was due to the ease with which the population increased since they were already established. Thus a total of $2579 \mathrm{~cm}^{3}$ of biogas was produced at the end of 22 days. The results obtained from these various 
experimental set ups corroborate those Imonite (2009) who used cow dung mixed with poultry droppings and fruit peelings.

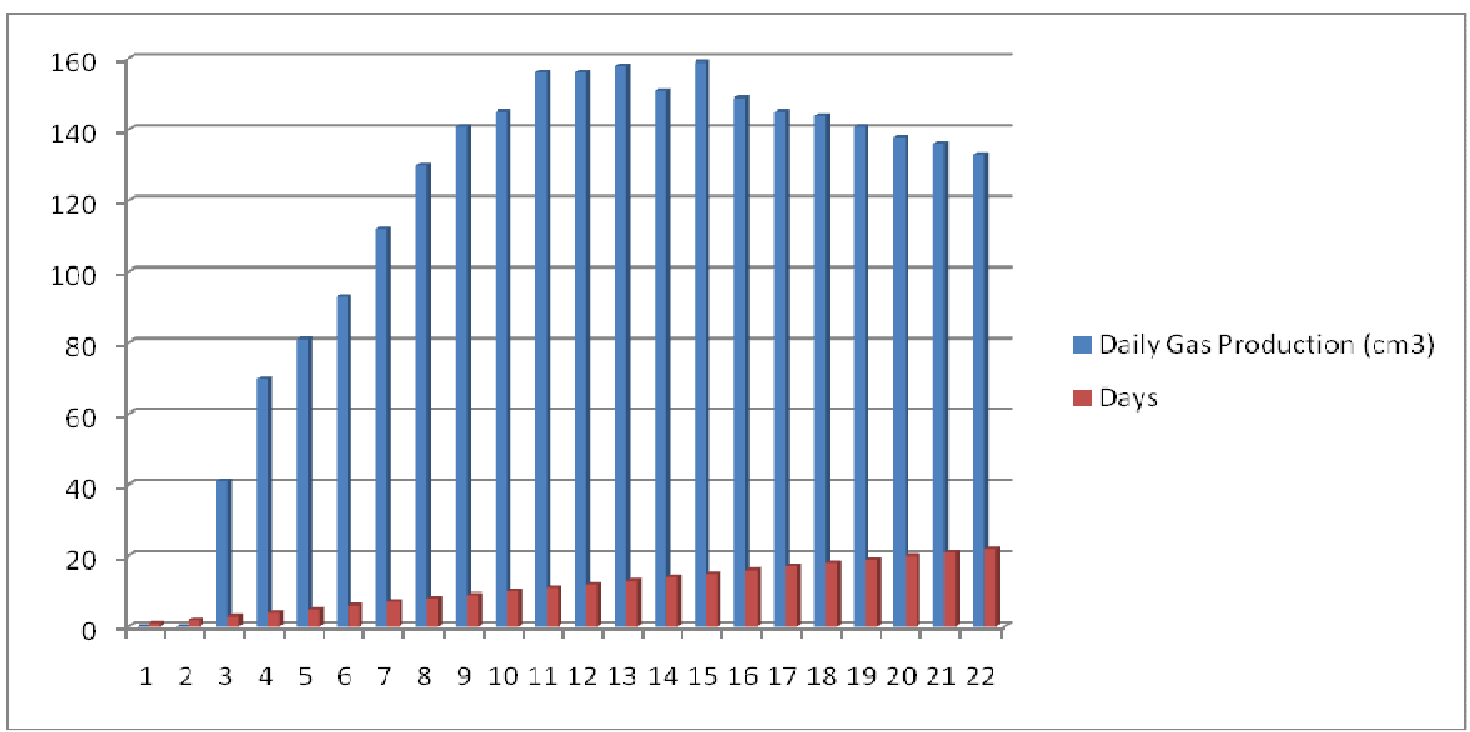

Figure 3: Gas produced for a restarted digester

\section{Conclusion and Recommendation}

Mixtures of cow dung and domestic organic wastes are good source for optimum gas production when they were prepared in varied proportion. The most suitable was $50 \%$ cow dung and 50\% weed which gave the maximum volume of gas within a period of 22 days. A restarted digester was also found to produce a reasonable quantity of biogas compared to those of several proportions. Biogas produced had the characteristic of a methane gas. It is therefore recommended that various domestic organic wastes could act as good source of biogas and help in solving problem of agricultural waste management.

\section{Acknowledgment}

Dr Sogbaike, E.C (Rector of Delta State Polytechnic, Otefe) and Staff of Science Laboratory Technology Department in Chemistry Laboratory are hereby acknowledged for the use of their laboratory facilities for this experiment.

\section{References}

Karla, M.S (1990). Anaerobic Digestion of crop residue, Encyclopedia of Environmental Technology, Gulf Publishing Company, Volume $4 \mathrm{Pp}$ $391-448$.

Diavwairu, A.D. (2006). Production of Biogas by the Anaerobic Digestion of Domestic Organic Waste and Weeds, HND Final Year Project, Department of Industrial Safety and Environmental Technology, Petroleum Training Institute, Effurun, Nigeria.

Eruedede, E.T. (2012). Importance and Implications of Production of Biogas from Cow dung and other farm manure. Department of Science Laboratory Technology, Delta State Polytechnic, Otefe, Oghara. 
Production of Biogas from Cow Dung, Weeds and Domestic Wastes.................NWUKEME et al.

Fowler, R. and Joshi, W. (1994). Anaerobic fermentation of newspapers, filter, paper, and banana skins. The Indian Institute of Science, Bangalore, India

Imonitie, I.D. (2009). Comparative analysis of biogas production from mixtures of cow dung and poultry droppings. Department of Chemical
Sciences, Novena University, Ogume, Nigeria

Nianguo, L.D. (1987). Microbial Technology in the Developing World, Oxford University Press, New York. P

Winfrey, M.R. (1984). Petroleum Microbiology, Macmillan, New

York Pp. 164 - 168 